\title{
Natural variability in size and membrane stability of lysosomes in mussel digestive cells: seasonal and tidal zonation
}

\author{
Urtzi Izagirre ${ }^{1}$, Ruth R. Ramos ${ }^{2}$, Ionan Marigómez ${ }^{1, *}$ \\ ${ }^{1}$ Laboratory of Cell Biology and Histology, Dept. Zoology and Animal Cell Biology, School of Science and Technology, \\ University of the Basque Country, 644 P.K., 48080 Bilbo, Basque Country, Spain \\ ${ }^{2}$ Dpto. Biología de Organismos, Universidad Simón Bolívar, Apdo. 89000, Caracas 1080-A, Venezuela
}

\begin{abstract}
Lysosomal responses in mussel digestive cells are widely accepted as effective biomarkers that respond to pollutant exposure, as well as to natural factors (tide, food, temperature). The effects of tide and season on digestive cell lysosomes in mussels were determined in different transect and transplant experiments on mussels at different tide levels and in winter and summer. We measured lysosomal enlargement through the lysosomal structural changes (LSC) test after $\beta$-glucuronidase ( $\beta$-Gus) histochemistry and membrane destabilisation through the lysosomal membrane stability (LMS) test after hexosaminidase (Hex) histochemistry. A marked gradient along the intertidal zone, which was more prominent in winter than in summer, was found in lysosomal size and membrane stability. A transplant experiment revealed that digestive cell lysosomes respond rapidly to immersion of mussels. The study of the time-course changes in mussels from high tidemark level indicated that lysosomes respond very promptly to air exposure conditions. We suggest that the lysosomal changes observed are the result of the digestive process in parallel with tide. Since such natural variability might mask the effects of pollution, we conclude that a standardised sampling protocol — which should include the use of mussels from low intertidal levels — is needed.
\end{abstract}

KEY WORDS: Lysosomes $\cdot$ Biomarkers $\cdot$ Tide $\cdot$ Season $\cdot$ Mytilus galloprovincialis $\cdot$ Digestive gland Resale or republication not permitted without written consent of the publisher

\section{INTRODUCTION}

Lysosomal responses in molluscan digestive cells constitute one of the most worldwide accepted biomarkers for assessing the health status of the marine environment (UNEP/RAMOGE 1999, Moore 2004, ICES 2005). In general terms, exposure to pollutants is known to cause significant increases in lysosomal size (Lowe et al. 1981, Moore et al. 1987, Etxeberria et al. 1994, Regoli et al. 1998, Marigómez \& Baybay-Villacorta 2003), as well as a reduction in lysosomal membrane stability (Moore et al. 1978, Harrison \& Berger 1982, Moore \& Clarke 1982, Nott \& Moore 1987, Moore 1988, Regoli 1992, Krishnakumar et al. 1994, Marigómez et al. 2005). In addition, lysosomal size and membrane stability may also change depending on natural environmental factors, such as temperature, salinity, food availability and tidal cycle (Moore 1976, Stickle et al. 1985, Marigómez et al. 1991, Tremblay \& Pellerin-Massicotte 1997, Abele et al. 1998). These factors are usually kept constant in controlled laboratory experiments conducted to investigate lysosomal responses to pollutants, but they may produce unexpected results in field studies (Regoli 1992). Consequently, how these natural factors may affect lysosomal size and membrane stability is a matter of undeniable applied interest.

Seasonal changes have been thoroughly reported in diverse aspects of the biology of mussels, including scope for growth, respiration and excretion, feeding physiology, pollutant tissue burdens, susceptibility to parasites and pathogens, and biomarker responses 
(Santarem et al. 1994, Soto et al. 1995, Baumard et al. 1999, Wong \& Cheung 2001, 2003, Huang \& Newell 2002, Ringwood et al 2002, Manduzio et al. 2004, Ivankovic et al. 2005). Particularly, lysosomal size and numbers (Etxeberria et al. 1995) and lysosomal membrane stability (Ringwood et al. 2002) show marked seasonal changes. Gonad development (Cáceres-Martínez \& Figueras 1998), food composition and food availability (Wong \& Cheung 2003) are believed to be major factors governing seasonality in mussels (Etxeberria et al. 1995, Leiniö \& Lehtonen 2005). The amplitude of seasonal variability may differ between species (Leiniö \& Lehtonen 2005) and between localities (Petrovic et al. 2004), and it has been suggested that it is largely attenuated in stressed populations (Marigómez et al. 1996). Accordingly, lysosomal membrane stability in mussel digestive gland was highly variable through the year in a clean site whereas in a polluted site values were lower and more constant between seasons (Regoli 1992).

Intertidal sessile organisms must cope with the changing physical conditions of both marine and terrestrial regimes. In the particular case of intertidal mussels, thermal stress (Helmuth \& Hofmann 2001), desiccation, anoxia (Moore et al. 1979, Hole et al. 1995), wave beating (Hunt \& Scheibling 2001), reduced food availability and progression of the digestion process (Charles \& Newell 1997) are major challenges during the periods of emersion. In contrast, subtidal mussels inhabit a less variable environment (Hunt \& Scheibling 2001), although differences between high and low tide, such as sediment resuspension or food quality, might also govern some aspects of their physiology (Zaldibar et al. 2004, 2008, Zardi et al. 2006). As a result, intertidal mussels exhibit a greater capacity to adapt to environmental changes more readily than subtidal ones (Charles \& Newell 1997). Intertidal and subtidal bivalves differ in their physiological energetics (Labarta et al. 1997), protein expression pattern (López et al. 2001) and digestion process (Robinson \& Langton 1980, Morton 1983).

In the mussel Mytilus edulis, the effect of the tide on lysosomal stability was investigated by Tremblay \& Pellerin-Massicotte (1997), who concluded that the lysosomal membrane was destabilised during emersion (labilisation period [LP] under $5 \mathrm{~min}$ ) and stabilised during immersion (LP > $25 \mathrm{~min}$ ). According to these authors, the incidence of phasic digestion rhythms could not be discarded, although air exposure and associated hypoxia might be the factors explaining the observed lysosomal responses.

Aimed at achieving a more feasible application of lysosomal biomarkers in marine pollution monitoring programmes, the purposes of the present study were (1) to determine the range of variability in form and function of digestive-cell lysosomes in intertidal mus- sels at different seasons and tidal conditions, and (2) to contribute to the understanding of the changes in lysosomal size and membrane stability under normal conditions. Thus, 3 complementary experiments were carried out. In the first experiment, the digestive-cell lysosomes of mussels collected from various levels in an intertidal transect were examined during 2 different seasons (winter and summer). In the second experiment, mussels were transferred from high to low tidemark level and vice versa in order to determine whether lysosomal size and membrane stability are characteristic of each tidemark level, or whether lysosomes exhibit prompt responses to environmental changes (i.e. air exposure vs. immersion). The third experiment consisted of a time-course sampling at the high tidemark level, in order to describe changes in lysosomal size and membrane stability during a tidal cycle in fully intertidal mussels that have a very short period for feeding during immersion.

\section{MATERIALS AND METHODS}

Experimental design and sample processing. Expt 1: In winter (March) and summer (August) 2001, mussels Mytilus galloprovincialis Lmk. were collected in Gorliz (Biscay Coast, 43 $26^{\prime} \mathrm{N}, 2^{\circ} 55^{\prime} \mathrm{W}$ ), a relatively non-polluted site (Orbea et al. 2006) on the protected side of a breakwater adjacent to the beach, following a transect throughout the tidal zone. Mussels were sampled from subtidal ( $0 \mathrm{~m}$ tidemark level) and intertidal $(0.5,1,1.5,2,2.5$ and $3 \mathrm{~m}$ tidemark level) zones. Subtidal mussels could not be obtained in August, since they were covered with sand.

Expt 2: In order to determine whether mussels from each tidemark level possess characteristic lysosomal structure and membrane stability resulting from an adaptation to each particular tidal regime, or whether lysosomes are highly responsive to emersion/immersion during the tidal cycle, the short-term lysosomal responses were investigated in mussels transplanted among tidemark levels in summer 2001. High tide (HT) mussels (from $3 \mathrm{~m}$ tidemark level) were kept submerged in sea water for 1 and $4 \mathrm{~h}$, and low tide (LT) mussels (from $0.5 \mathrm{~m}$ tidemark level) were subjected to air exposure for $4 \mathrm{~h}$.

Expt 3: This experiment was designed to investigate the timing of changes in lysosomal structure and membrane stability for a given tidemark level, HT, which was selected as representative of an extreme tidal regime. In summer (August) 2005 (after the effects of the November 2002 Prestige oil spill were shown to remit significantly; Cajaraville et al. 2006), HT mussels (from the 2.5 to $3 \mathrm{~m}$ level) were sampled, from the same breakwater as that in the previous experiment at suc- 
cessive time intervals: 30 min before emersion during a normal tide cycle $(07: 20 \mathrm{~h})$, immediately just before emersion (07:50 h), every following hour (08:50, 09:50, 10:50, 11:50, 12:50 and 13:50 h) during aerial exposure, and a further 30 and 45 min after immersion into seawater during the next high tide (14:20 and 14:35 h).

Five mussels (3 to $4.5 \mathrm{~cm}$ shell length) were taken per sample. In Expts 1 and 2, digestive gland was excised and rinsed in phosphate buffer $0.1 \mathrm{M}(\mathrm{pH} 7.4$, sucrose $10 \%$ ) for $15 \mathrm{~min}$, embedded in Cryo-M-Bed and frozen in liquid nitrogen $\left(-196^{\circ} \mathrm{C}\right)$. In Expt 3, digestive gland was removed and placed on plastic chucks aligned in a straight row, put into cryovials and directly frozen in liquid nitrogen.

Frozen samples were transported to the laboratory in liquid nitrogen and then stored at $-80^{\circ} \mathrm{C}$ until required for analysis. Tissue sections (8 to $10 \mu \mathrm{m}$ thick, depending on the staining method) were obtained in a Leica CM3000 cryotome with a chamber temperature of $-24^{\circ} \mathrm{C}$. Sections were stored at $-40^{\circ} \mathrm{C}$ until required for staining.

Lysosomal structural changes (LSC). The histochemical reaction for $\beta$-glucuronidase ( $\beta$-Gus) was demonstrated as in Moore (1976), with the modifications as described by Cajaraville et al. (1989). Slides were held at $4^{\circ} \mathrm{C}$ for $30 \mathrm{~min}$ and then at room temperature for $5 \mathrm{~min}$ prior to staining. Sections $(8 \mu \mathrm{m})$ were incubated in freshly prepared $\beta$-Gus substrate incubation medium consisting of $28 \mathrm{mg}$ naphthol AS-BI- $\beta$-glucuronide (Sigma, N1875) dissolved in $1.2 \mathrm{ml}$ of $50 \mathrm{mM}$ sodium bicarbonate, made up to $100 \mathrm{ml}$ with $0.1 \mathrm{M}$ acetate buffer (pH 4.5) containing $2.5 \% \mathrm{NaCl}$ and $15 \%$ of polyvinyl alcohol and held for $40 \mathrm{~min}$ at $37^{\circ} \mathrm{C}$ in a shaking water bath. After incubation, slides were rinsed in a $2.5 \%$ $\mathrm{NaCl}$ saline solution for $2 \mathrm{~min}$ at $37^{\circ} \mathrm{C}$ in a shaking water bath and then transferred to a postcoupling medium containing $0.1 \mathrm{~g}$ Fast Garnet (GBC) (Sigma, F8716) dissolved in $100 \mathrm{ml}$ of $0.1 \mathrm{M}$ phosphate buffer (pH 7.4, containing $2.5 \% \mathrm{NaCl}$ ) for 10 min in darkness and at room temperature. Afterwards, sections were fixed for $10 \mathrm{~min}$ at $4^{\circ} \mathrm{C}$ in Baker's formol calcium containing $2.5 \% \mathrm{NaCl}$ and rinsed briefly in distilled water. Finally, sections were counterstained with $0.1 \%$ Fast Green FCF (Sigma, F7252) for 2 min, rinsed several times in distilled water and mounted in Kaiser's glycerol gelatine and sealed with nail varnish.

A stereological procedure was applied in order to quantify the structure of the digestive cell lysosomes, with the aid of an automated image analysis system (BMS, Sevisan; Cajaraville et al. 1995). Slides were viewed using an objective lens of $100 \times$ magnification on a light microscope. Five measurements were made per section in each of the 5 specimens comprising each experimental group, in order to calculate the following stereological parameters (Lowe et al. 1981): lysosomal volume density $(\mathrm{Vv}=\mathrm{V}[\mathrm{L}] / \mathrm{V}[\mathrm{C}])$, lysosomal surface density $(\mathrm{Sv}=\mathrm{S}[\mathrm{L}] / \mathrm{V}[\mathrm{C}])$, lysosomal surface to volume ratio (S/V = S $[\mathrm{L}] / \mathrm{V}[\mathrm{L}])$ and lysosomal numerical density $(\mathrm{Nv}=\mathrm{N}[\mathrm{L}] / \mathrm{V}[\mathrm{C}])$, where $\mathrm{V}=$ volume, $\mathrm{S}=$ surface, $\mathrm{N}=$ number, $\mathrm{L}=$ lysosomes and $\mathrm{C}=$ digestive cell cytoplasm for mussels. The stereological formulae include a correction factor for particles with an average diameter smaller than the section thickness (Lowe et al. 1981).

Lysosomal membrane stability (LMS) test. The determination of lysosomal membrane stability was based on the time of acid labilisation treatment required to produce the maximum staining intensity according to UNEP/RAMOGE (1999), after demonstration of hexosaminidase activity in digestive cell lysosomes.

Slides were held at $4^{\circ} \mathrm{C}$ for $30 \mathrm{~min}$ and at room temperature for $5 \mathrm{~min}$ prior to staining. Serial cryotome sections $(10 \mu \mathrm{m})$ were subjected to acid labilisation at intervals of $0,3,5,10,15,20,30$ and $40 \mathrm{~min}$ in $0.1 \mathrm{M}$ citrate buffer ( $\mathrm{pH} 4.5$, containing $2.5 \% \mathrm{NaCl}$ ) in a shaking water bath at $37^{\circ} \mathrm{C}$, in order to determine the range of pre-treatment time needed to completely labilise the lysosomal membrane. Following this treatment, sections were transferred to the substrate incubation medium for the demonstration of hexosaminidase (Hex) activity, consisting of $20 \mathrm{mg}$ naphthol AS-BI-N-acetyl- $\beta$-D-glucosaminide (Sigma, N 4006) dissolved in $2.5 \mathrm{ml}$ of 2-methoxyethanol (Merck, 859), and made up to $50 \mathrm{ml}$ with $0.1 \mathrm{M}$ citrate buffer ( $\mathrm{pH} 4.5$ ) containing $2.5 \% \mathrm{NaCl}$ and $3.5 \mathrm{~g}$ of low-viscosity polypeptide (Sigma, P5115) to act as a section stabiliser. Sections were incubated in this medium for $20 \mathrm{~min}$ at $37^{\circ} \mathrm{C}$, rinsed in a saline solution $(3.0 \% \mathrm{NaCl})$ at $37^{\circ} \mathrm{C}$ for $2 \mathrm{~min}$ and transferred to $0.1 \mathrm{M}$ phosphate buffer ( $\mathrm{pH}$ 7.4) containing $1 \mathrm{mg} \mathrm{ml}^{-1}$ of diazonium dye Fast Violet B salt (Sigma, F1631), at room temperature for $10 \mathrm{~min}$. Slides were then rapidly rinsed in running tap water for $5 \mathrm{~min}$, fixed for $10 \mathrm{~min}$ in Baker's formol calcium containing $2.5 \% \mathrm{NaCl}$ at $4^{\circ} \mathrm{C}$ and rinsed in distilled water. Finally, slides were mounted in Kaiser's glycerin gelatine and sealed with nail varnish.

The time of acid labilisation treatment required to produce the maximum staining intensity was assessed under a light microscope as the maximal accumulation of reaction product associated with lysosomes (UNEP/RAMOGE 1999). Four determinations were made for each animal by dividing each section in the acid labilisation sequence into 4 approximately equal segments and assessing the labilisation period (LP) in each of the corresponding set of segments. The mean value was then derived for each section, corresponding to an individual digestive gland.

Statistics. Statistical analyses were carried out with the aid of SPSS/PC+ statistical package (SPSS) and SPSS v. 10.0 for Windows. For the statistical analysis of LP the non-parametric Mann-Whitney $U$-test was 
applied. Stereological parameters were tested using 1 -way ANOVAs $(\mathrm{p}<0.05)$. Data for lysosomal $\mathrm{Vv}$ and Nv were logarithmically transformed in samples from Expt 1 prior to the statistical analyses since the variance within individual mussels depended on the mean. Significant differences between pairs of mean values were established using Duncan's test $(p<0.05)$.

\section{RESULTS}

\section{Expt 1}

LP values recorded in lysosomes of mussel digestive cells differed among tidemark levels, both in winter and summer, following a continuous gradient with lowest LP values at highest tidemark levels (Fig. 1).
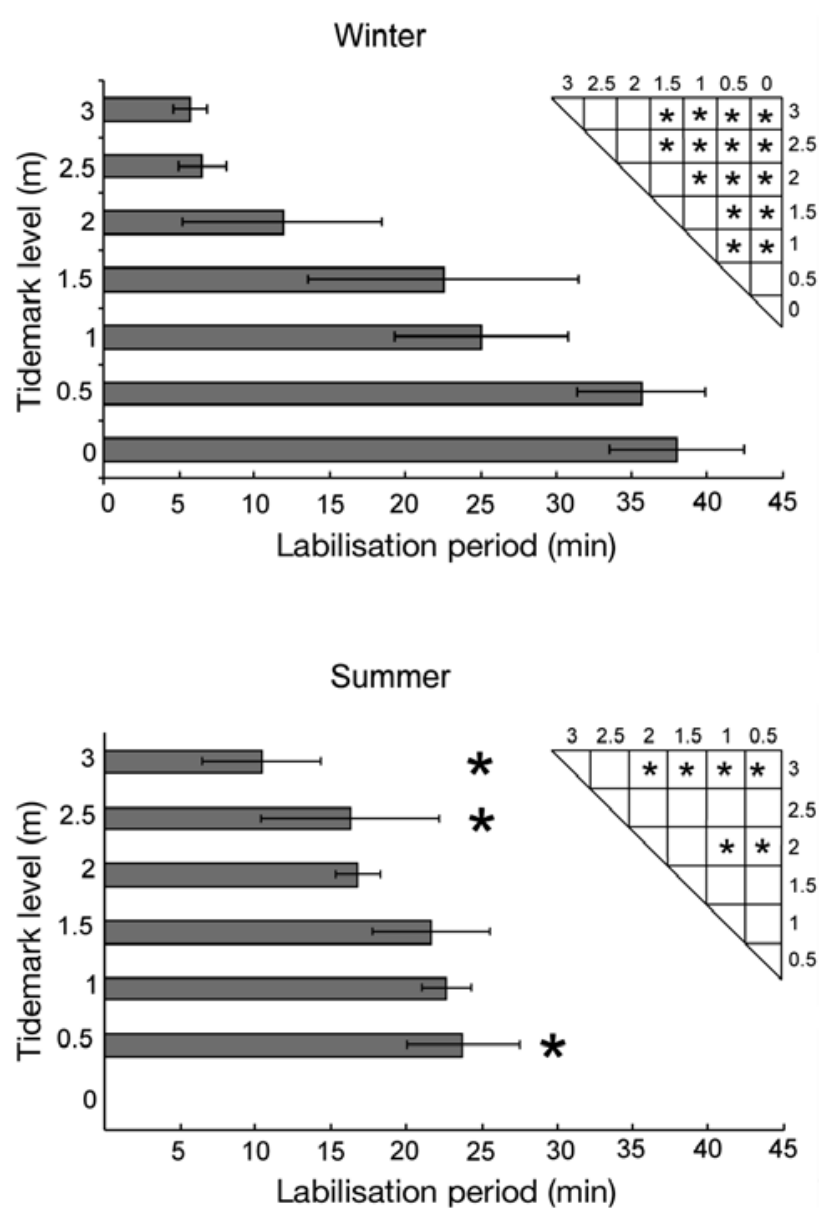

Fig. 1. Mytilus galloprovincialis. Labilisation period (min) of mussels from different tidemark levels collected in March (winter) and August (summer) 2001. Error bars indicate SD. Asterisks in the triangular matrices indicate significant differences between means along the intertidal transect after the Mann-Whitney $U$-test $(p<0.05)$. Asterisks beside bars in summer graph indicate significant differences between seasons for the corresponding tidemark levels $(U$-test, $\mathrm{p}<0.05)$
The range of variation in LP values between mussels from high and low tidemark levels was wider in winter than in summer. Thus, in LT (subtidal) mussels, LP values were higher in winter than in summer, whereas in HT (3 m) mussels, LP values were higher in summer than in winter (Fig. 1).

The digestive cell lysosomes of winter LT mussels were abundant but too small to be measured by image analysis since their size was below the system resolution limit. In contrast, the digestive cell lysosomes of winter HT mussels were apparently less numerous but large enough to be measured; yet lysosomes were also very small as shown by S/V values close to 6 (Fig. 2) and, in general terms, the endo-lysosomal system was poorly developed ( $\mathrm{Vv}<0.001$; Fig. 2A).

The digestive cell lysosomes of mussels were more conspicuous in summer than in winter, especially at LT level. The stereological parameters recorded in summer HT mussels were similar to those recorded in winter HT mussels (Fig. 2). In summer LT mussels, however, the structure of digestive cell lysosomes varied significantly with tidemark level (ANOVA, p < 0.05). $\mathrm{Vv}, \mathrm{Sv}$ and $\mathrm{Nv}$ values were higher in LT mussels than in HT mussels, whereas S/V was lower (Fig. 2B). It must be noted that in LT mussels lysosomes were tiny in winter but markedly larger in summer (Fig. 2).

\section{Expt 2}

In order to determine whether mussels from each tidemark possess characteristic lysosomal structure and membrane stability resulting from an adaptation to each particular tidal regime or whether lysosomes are simply highly responsive to emersion or immersion, mussels were transplanted among tidemark levels to examine the short-term lysosomal responses. Thus, HT mussels originating at $3 \mathrm{~m}$ were submerged for a period of $1 \mathrm{~h}(1-\mathrm{W})$ and $4 \mathrm{~h}(4-\mathrm{W})$, maintained at the same tidemark level as LT $(0.5 \mathrm{~m})$ mussels, whereas LT mussels were kept out of seawater for $4 \mathrm{~h}$ (A). A, 1-W and 4-W mussels showed similar LP values, comparable to those recorded in HT mussels and significantly different from those of LT mussels (Fig. 3). Thus, although LP values in A mussels reached values close to those found in HT mussels, immersion in seawater for up to $4 \mathrm{~h}$ was not sufficient to attain the LP values recorded in LT $(0.5 \mathrm{~m})$ mussels (Fig. 3).

In contrast, more dynamic changes were registered in the lysosomal structure, as revealed by the 4 stereological parameters calculated (Fig. 4). Already, after $1 \mathrm{~h}$ in seawater, $\mathrm{Vv}$ and $\mathrm{S} / \mathrm{V}$ values were more similar to those recorded in LT $(0.5 \mathrm{~m})$ mussels than in the source HT (3 m) mussels. Likewise, keeping mussels exposed for $4 \mathrm{~h}$ was sufficient to take $\mathrm{Vv}$ values from 

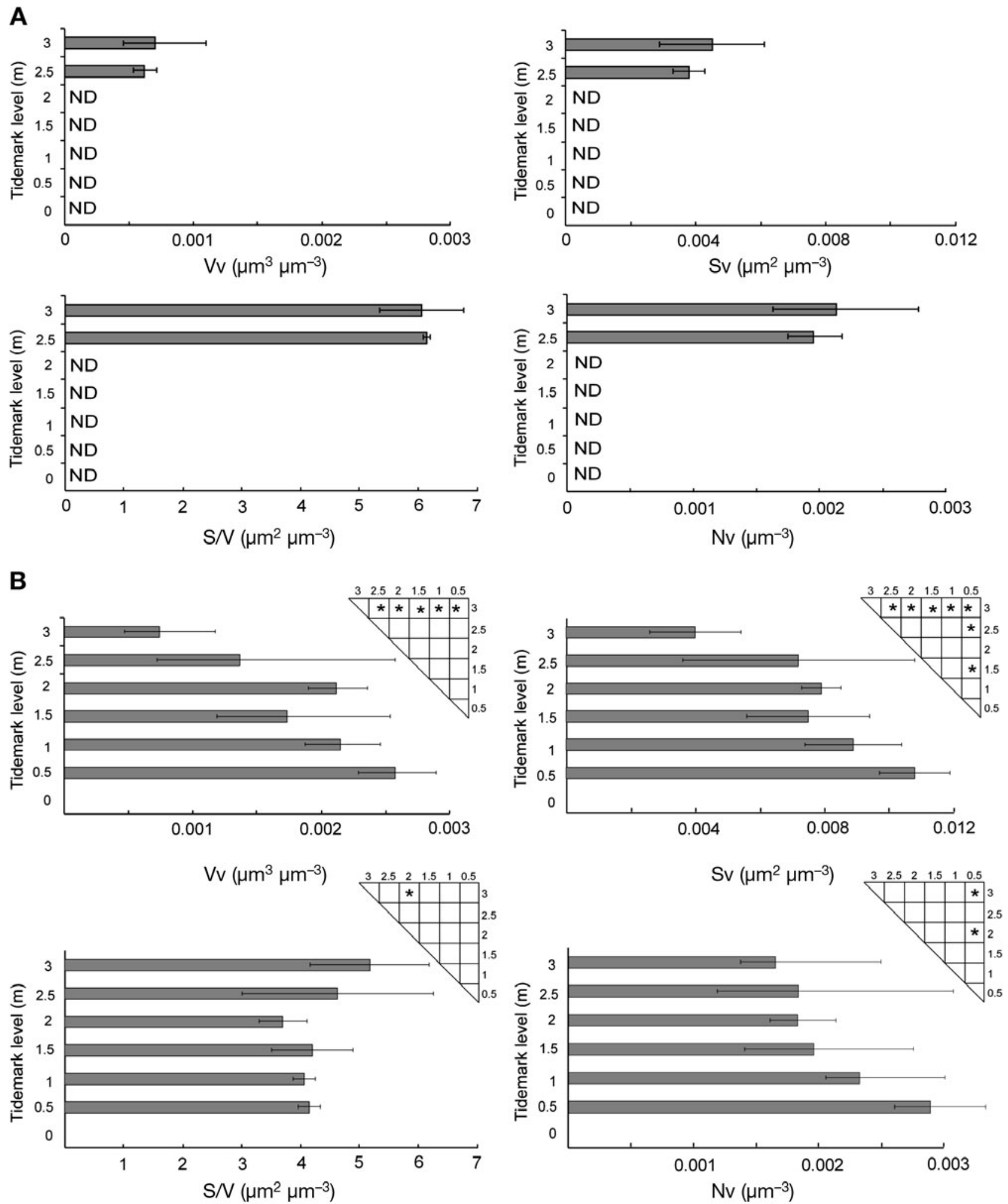

Fig. 2. Mytilus galloprovincialis. Stereological parameters of digestive cell lysosomes of mussels from different tidemark levels collected in (A) March (winter) and (B) August (summer) 2001. Intervals indicate SD and asterisks indicate significant differences between pairs of means after Duncan's test (ANOVA, $\mathrm{p}<0.05$ ). Vv: lysosomal volume density; Sv: lysosomal surface density; S/V: lysosomal surface to volume ratio; Nv: lysosomal numerical density; ND: not detectable 


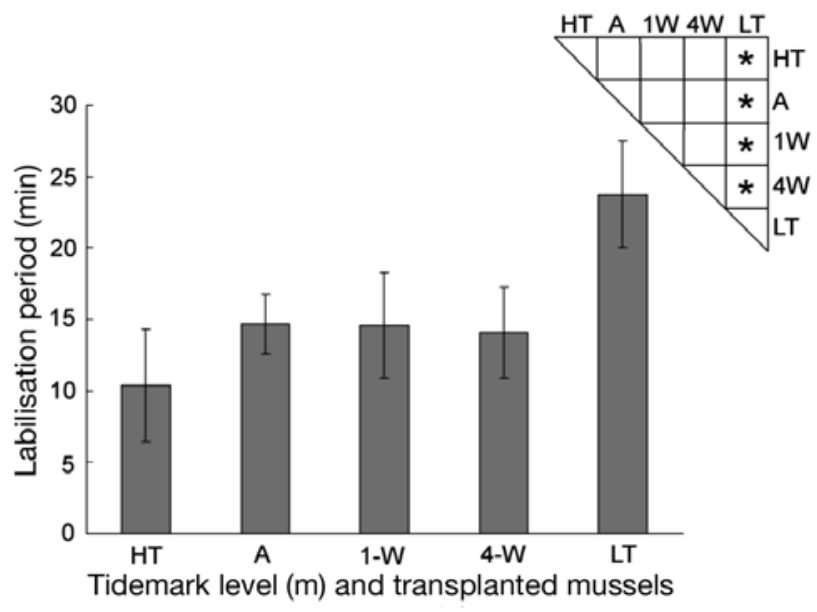

Fig. 3. Mytilus galloprovincialis. Labilisation period (min) of digestive cell lysosomes of transplanted mussels (A: low tidemark [LT, $0.5 \mathrm{~m}$ ] mussels exposed for $4 \mathrm{~h}$; 1 -W: high tidemark [HT, $3 \mathrm{~m}$ ] mussels immersed for $1 \mathrm{~h}$ 4-W: HT mussels immersed for $4 \mathrm{~h}$ ) and source mussels (HT and LT mussels). Error bars indicate SD. Asterisks indicate significant differences between pairs ofmeans (Mann-WhitneyU-test $p<0.05$ )
$0.002 \mu \mathrm{m}^{3} \mu^{-3}$ (recorded in LT mussels) to values below $0.001 \mu^{3} \mu^{-3}$ (corresponding to HT mussels). $\mathrm{Nv}$ in $4-\mathrm{W}$ mussels changed to values recorded in LT mussels, with an evident trend (non significant) already after $1 \mathrm{~h}$ immersion (1-W mussels; Fig. 4).

\section{Expt 3}

Significant time-course variations were found in lysosomal membrane stability in HT $(2.5 \mathrm{~m})$ mussels throughout a tidal cycle. The highest LP values (around $15 \mathrm{~min}$ ) were recorded at the end of the immersion period (Fig. 5). Air exposure for $1 \mathrm{~h}$ was sufficient to reduce LP values significantly (beyond 50\%) and then extremely low LP values were recorded for the following hours during emersion. Finally, the stability of the lysosomal membrane increased very rapidly following the next tide rise (Fig. 5).

Significant differences in lysosomal size and numbers were also recorded between sampling times, but changes did not occur fully in parallel with changes in
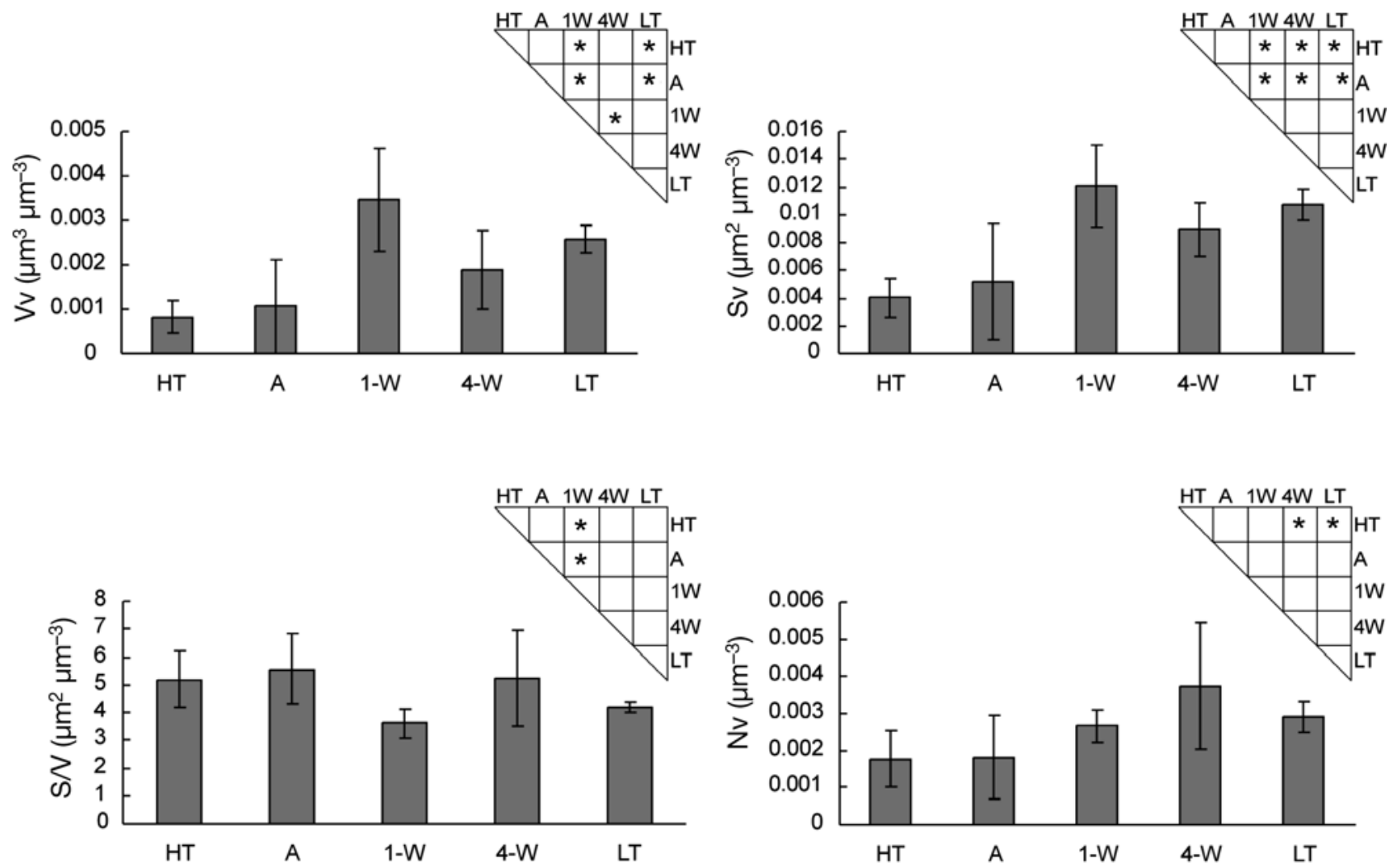

Fig 4. Mytilus galloprovincialis. Stereological parameters of digestive cell lysosomes of transplanted mussels (A: LT mussels exposed for $4 \mathrm{~h}$; 1 -W: HT mussels immersed for $1 h_{i} 4$-W: HT mussels immersed for $4 \mathrm{~h}$ ) and mussels sampled at both ends of the transect (HT and LT mussels; see Fig. 3). Error bars show SD and asterisks show significant differences between pairs of means (ANOVA, p < 0.05) using Duncan's test. Parameter abbreviations as in Fig. 2 


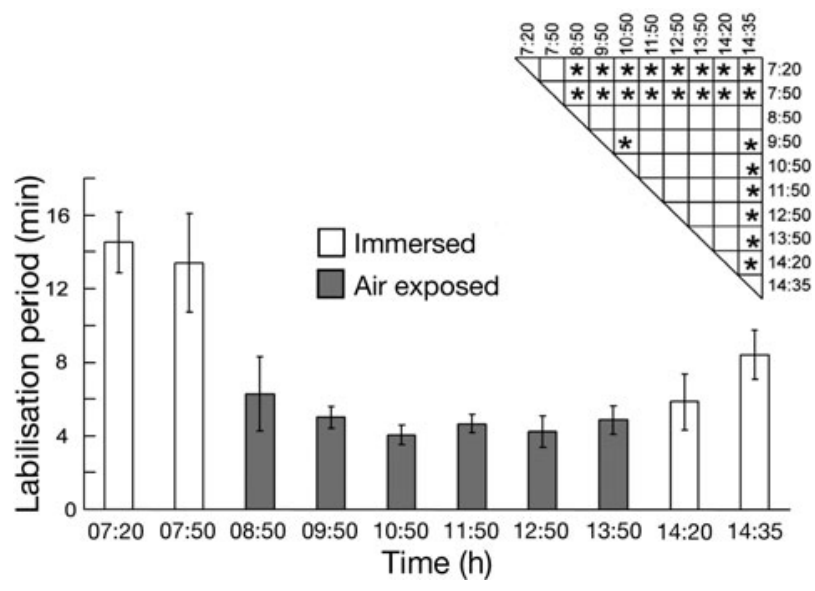

Fig. 5. Mytilus galloprovincialis. Labilisation period (min) of digestive cells of mussels at high tidemark level in summer 2005 over a period of exposure between 2 immersion periods. Error bars indicate SD and asterisks indicate significant differences (Mann-Whitney $U$-test, $\mathrm{p}<0.05$ )

membrane stability. The lowest $\mathrm{Vv}$ and $\mathrm{Sv}$ and highest $\mathrm{S} / \mathrm{V}$ values were recorded at the end of the immersion period (Fig. 6). Air exposure for $1 \mathrm{~h}$ was also sufficient for $\mathrm{Vv}$ and $\mathrm{Sv}$ to rise significantly (Fig. 6), but the return to the previous values started before the next tide rise, approximately $4 \mathrm{~h}$ after emersion. This return is not accomplished by increases in lysosomal size but by reduction in lysosomal numbers.

\section{DISCUSSION}

The lysosomes of molluscan digestive cells are responsive to pollutant exposure (Lowe \& Clarke 1989, Marigómez et al. 1989, 1996, 2006, Regoli 1992, Viarengo et al. 1992, Etxeberria et al. 1994, Regoli et al. 1998, Marigómez \& Baybay-Villacorta 2003), but also to changes in natural factors (Moore 1976, Pipe \& Moore 1985, Stickle et al. 1985, Moore et al. 1987, Marigómez et al. 1991, Tremblay \& Pellerin-Massicotte 1997, Abele et al. 1998). It is therefore necessary to determine the range of natural variability in lysosomal form and function, and how such variability might interfere with the correct interpretation of lysosomal biomarkers in the assessment of the biological effects of pollution. Herein, the natural variability in size and membrane stability of lysosomes in mussel digestive cells has been investigated in relation to tidal regime and season.

\section{Tidal regime}

The present results reveal that lysosome membrane stability may vary tremendously, ranging from values below $10 \mathrm{~min}$ (HT mussels) to values over $20 \mathrm{~min}$ (LT
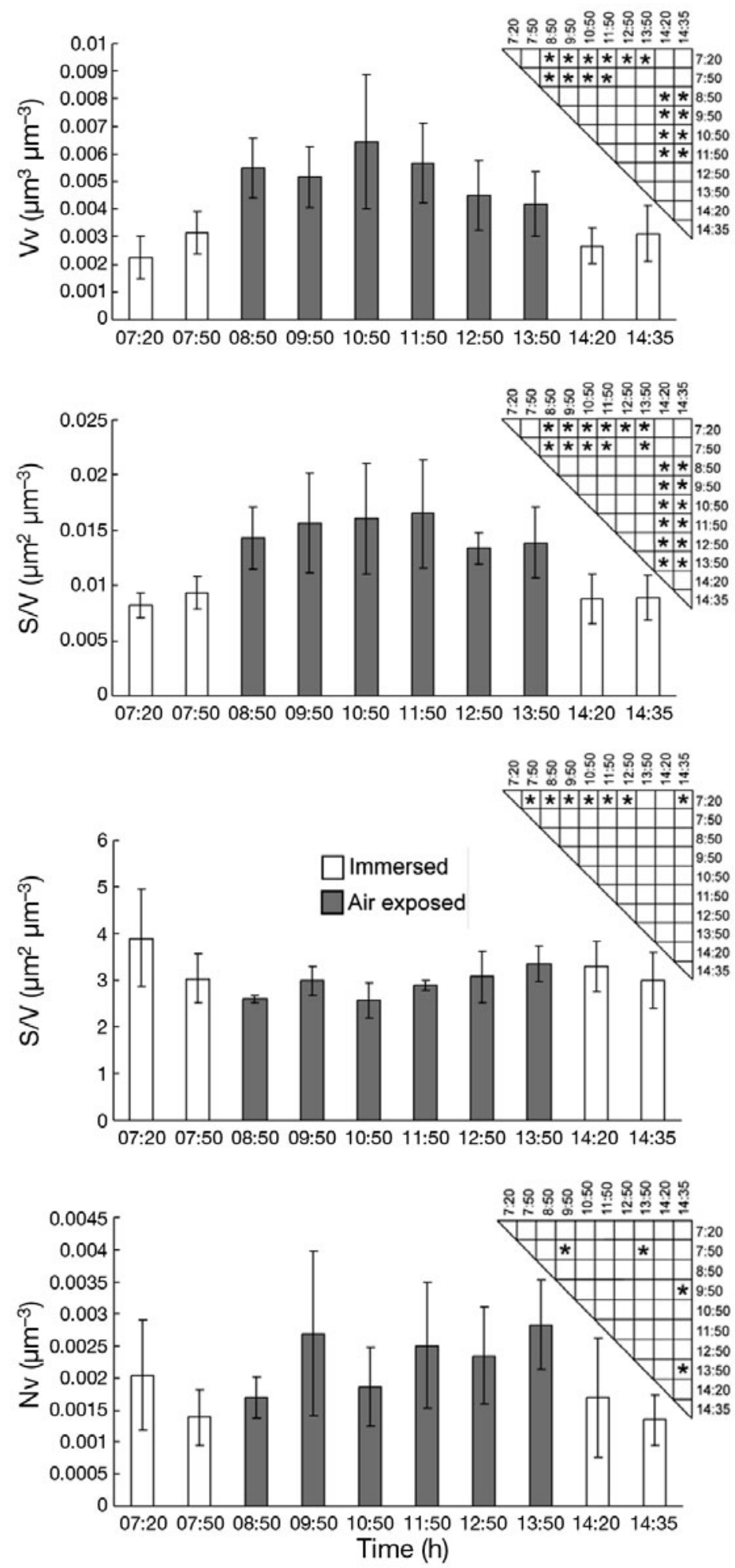

Fig. 6. Mytilus galloprovincialis. Stereological parameters of digestive cell lysosomes of transplanted mussels at high tidemark level in summer 2005 over a period of exposure between 2 immersion periods. Error bars indicate SD and asterisks show significant differences between pairs of means after Duncan's test $($ ANOVA, $p<0.05)$. Parameter abbreviations as in Fig. 2 
mussels), for the same locality and the same sampling day. Accordingly, Tremblay \& Pellerin-Massicotte (1997) found that LP in digestive cells of Mya arenaria and Mytilus edulis from a given sampling point can vary from 5 to $30 \mathrm{~min}$ throughout the time within the tidal cycle. According to these authors, air exposure and hypoxia during emersion might induce autophagy to compensate for extra energetic demand, which would be reflected in low LP values recorded during emersion.

Mussels are known to elicit behavioural and physiological responses to emersion in order to enhance respiratory gas exchange (Sadok et al. 1999). Thus, effective short-term hypoxia does not seem to be a major event. Moreover, prolonged anoxia and temperature stress have been shown to produce lysosomal membrane destabilisation in molluscan digestive cells (Moore 1976, Moore et al. 1978, Stickle et al. 1985), but it seems unfeasible that short-term hypoxia associated with emersion during each tidal cycle causes such marked membrane destabilisation. Even so, LP values close to 5 min have been seldom recorded after exposure to very high concentrations of pollutants in the laboratory (Lowe \& Clarke 1989, Viarengo et al. 1992, Moore 2004, Izagirre 2007) and in field studies concerning cases of severe pollution (Regoli 1992, Regoli et al. 1998, Marigómez et al. 2005, 2006).

Temperature stress might also be responsible for dramatic lysosomal membrane destabilisation but, again, at least a few days' maintenance at $13^{\circ} \mathrm{C}$ over ambient temperatures is required to induce a significant decrease in LP values in mussels (Moore 1976). In the present study, water temperature was about 21 to $22^{\circ} \mathrm{C}$ and air temperature was 24 to $25^{\circ} \mathrm{C}$ in the sampling station in August. In addition, gapping and biochemical regulation can control short-term thermal stress in mussels, variations in internal temperature being much less pronounced than in the surrounding milieu (Helmuth \& Hofmann 2001). It seems therefore that temperature is not the cause for the variability found in lysosomal structure and membrane destabilisation.

Alternatively, it is conceivable that differences in the progression of food digestion might explain the differences found in LP values along the intertidal zone, as pointed out by Tremblay \& Pellerin-Massicotte (1997). As a matter of fact, intracellular digestion is the main function of the extraordinarily developed endo-lysosomal system of mussel digestive cells (Robledo \& Cajaraville 1996).

In intertidal bivalves, feeding and digestion are cyclic processes that match up with tidal cycles (Morton 1983). Structure and function of digestive cells, including their endo-lysosomal system, undergo dramatic changes during the intracellular digestion process, which take place every tidal cycle (Langton 1977, Robinson \& Langton 1980, Morton 1983, Marigómez
2007). Different intracellular digestion phases can be recognised (e.g. absorption, digestion, disintegration and holding) as digestive cells change in size, shape and cytoplasmic contents. In HT intertidal bivalves, feeding is more intense during immersion, whereas digestion progresses during emersion and therefore tidal regime (and tidal zonation) and digestion regime are intimately related (Morton 1983). Emersion does not necessarily mean stress or a resting stage. Indeed, in the intertidal mussel Geukensia demissa, aerial respiration is enhanced so that the mussel can gain enough energy to facilitate food digestion during air exposure at low tide (Huang \& Newell 2002). Moreover, digestive enzyme activities, such as $\alpha$-amylase, differ between tidemark levels in Mytilus edulis (Langton 1977), which suggests the existence of different paces of intracellular digestion depending on the tidal regime (Wong \& Cheung 2001).

In digestive cells of winkles Littorina littorea the structure and histochemical properties of the endolysosomal system changes with tide as intracellular digestion progresses (Saez et al. 1990). In Mytilus galloprovincialis, it seems that around $50 \%$ of the lysosomes are lost every digestion cycle at the disintegrating phase and their numbers recover before the following absorption phase (Marigómez 2007). Accordingly, in mussels continuously submerged, the start of food digestion immediately after feeding is accompanied by a transient increase in number and size of lysosomes, together with membrane destabilisation (Izagirre 2007). These large lysosomes with destabilised membrane might well be heterolysosomes where food digestion is being accomplished. Thus, in order to clarify whether the structure and membrane stability of digestive cell lysosomes are characteristic of each tidemark level or change with digestion, we conducted Expts 2 and 3.

In Expt 2, the endo-lysosomal system of LT mussels exposed to air for $4 \mathrm{~h}$ (A mussels) resembles that of HT mussels in both structure and membrane stability, whereas in HT mussels kept submerged for 1 to $4 \mathrm{~h}$ (1-W and 4-W mussels) only lysosomal size and numbers approach those of LT mussels, while membrane stability remains unchanged. Overall, it can be concluded that the lysosomal parameters are not characteristic of each tidemark and that they may vary within a few hours during the tide, in agreement with Tremblay \& Pellerin-Massicotte (1997).

The question that remains is whether these changes are due to environmental stress or are normal changes occurring during digestion. As a matter of fact, it seems unconceivable that something stressful occurs for around $6 \mathrm{~h}$ twice every day. Nevertheless, let's suppose that LT mussels exposed to air for $4 \mathrm{~h}$ are stressed as revealed by low LP values: why is lysosomal size 
reduced (low $\mathrm{Vv}$ and high $\mathrm{S} / \mathrm{V}$ values) to the size of lysosomes in HT musssels? Low LP values may be indicative of environmental stress (ICES 2005, Marigómez et al. 2006) but it should be accompanied by lysosomal enlargement (Moore \& Viarengo 1987, Marigómez et al. 2005). On the other hand, it is conceivable that after $4 \mathrm{~h}$ of air exposure, LT mussels have reached a late stage of intracellular digestion (i.e. disintegrating), including few small lysosomes with destabilised membrane (Marigómez 2007).

Expt 3 sheds some light on this aspect, as the time course changes in lysosomal parameters was examined throughout 1 tide (digestion) cycle in HT mussels, where tidal rhythms can be expected to be most marked (Morton 1983). Lysosomal parameters change significantly with time for a given tidemark level. In agreement with Tremblay \& Pellerin-Massicotte (1997), lysosomal membrane destabilisation occurs when the tide comes down within a few minutes. Conversely, LP values are not fully recovered within $1 \mathrm{~h}$ submersion, although a trend to increase is envisaged as LP significantly increases. Likewise, lysosomal size increases with the emersion (high $\mathrm{Vv}$ and Sv and low $\mathrm{S} / \mathrm{V}$ values) for about $4 \mathrm{~h}$ and then starts decreasing (reduced Vv and Sv, and augmented S/V). Since feeding (immersion) and digestion (emersion) are clearly separated in bivalves from high tidemark levels (Morton 1983), these changes might be explained by the progression of food processing. Just $1 \mathrm{~h}$ after emersion, the increase in heterolysosomes (food digestion) might explain the decrease recorded in LP values and the increase in lysosomal size. Indeed, heterolysosomes are the largest compartments of the endo-lysosomal system in digestive cells and possess a destabilised membrane, as hydrolytic enzymes are active (Moore 1988). A positive correlation has been described between the amount of residual bodies (which become the dominant compartments later in the digestion process) and low LP values (Domouhtsidou \& Dimitriadis 2000). Nv is variable during emersion but decreases just within the first hour of a new immersion, possibly due to the excretion of residual bodies resulting from heterolysosomes at the last steps in the digestion process.

More research is needed to elucidate the relationship between lysosomal parameters and digestion (Izagirre 2007) but, at present, it can be hypothesised that different rhythms of intracellular digestion at different tidemark levels might be a major factor governing structure and function of the endo-lysosomal system in mussel digestive cells. A hypothetical model that fits well with our results is detailed in Fig. 7. The number and size of lysosomes, as well as their membrane stability vary with tide and digestion, depending on how long mussels are submerged at each tidemark level.
Thus, the number and size of lysosomes are reduced during tidal rise, when membrane stability increases, whereas the contrary occurs during tidal drawdown. In this manner, intertidal mussels, and especially HT mussels, would take advantage of high tide to take up as much food as possible and then perform intracellular digestion during emersion, which would result in abundant heterolysosomes with destabilised membranes at the sampling time. In contrast, subtidal mussels would have almost continuous food availability, making cyclic digestion more subtle, with less conspicuous changes in the morphology of digestive cells (Robinson \& Langton 1980), which would possess a more stable and homogeneous endo-lysosomal system comprised of abundant small lysosomes (results of the present study). It is worth noting that, at any given moment, there is not necessarily a simple direct relationship between lysosomal Vv and LP; therefore, the principle that enlargement precedes destabilisation (Marigómez \& Baybay-Villacorta 2003, Marigómez et al. 2006) must be considered with caution when lysosomal biomarkers are interpreted.

\section{Season}

In mussels from temperate regions, molecular and cellular processes are known to present a clear pattern of seasonal variability (Cancio et al. 1999, Manduzio et al. 2004, Petrovic et al. 2004, Ivankovic et al. 2005) that has been related to seasonal changes in temperature, food availability and gonad development (Etxeberria et al. 1995, Leiniö \& Lehtonen 2005). Along the Basque coast, the seasonal pattern of variation in water temperature and food availability is well known (Madariaga \& Orive 1989, Orive et al. 2004). Accordingly, lysosomal size and membrane stability present a marked seasonal variability in absolute terms, as well as in relation to the range of variation found along the intertidal zone, differences between mussels from different tidemark levels being less pronounced in summer than in winter.

In agreement with previous reports (Etxeberria et al. 1995, Marigómez et al. 1996), lysosomes are more conspicuous (high $\mathrm{Vv}_{\mathrm{V}} \mathrm{Sv}$ and low $\mathrm{S} / \mathrm{V}$ values) in summer than in winter and their membrane is more destabilised (low LP values). Indeed, lysosomes were abundant but tiny in winter and they could not be measured by image analysis in most samples. Tremblay et al. (1998) also found that LP values are lower in summer than in winter in mussel digestive cells. In mussels from the Adriatic coast, however, lysosomal membrane stability is less season-dependent than other biomarkers, even though stability is somehow reduced in summer (Petrovic et al. 2004). 


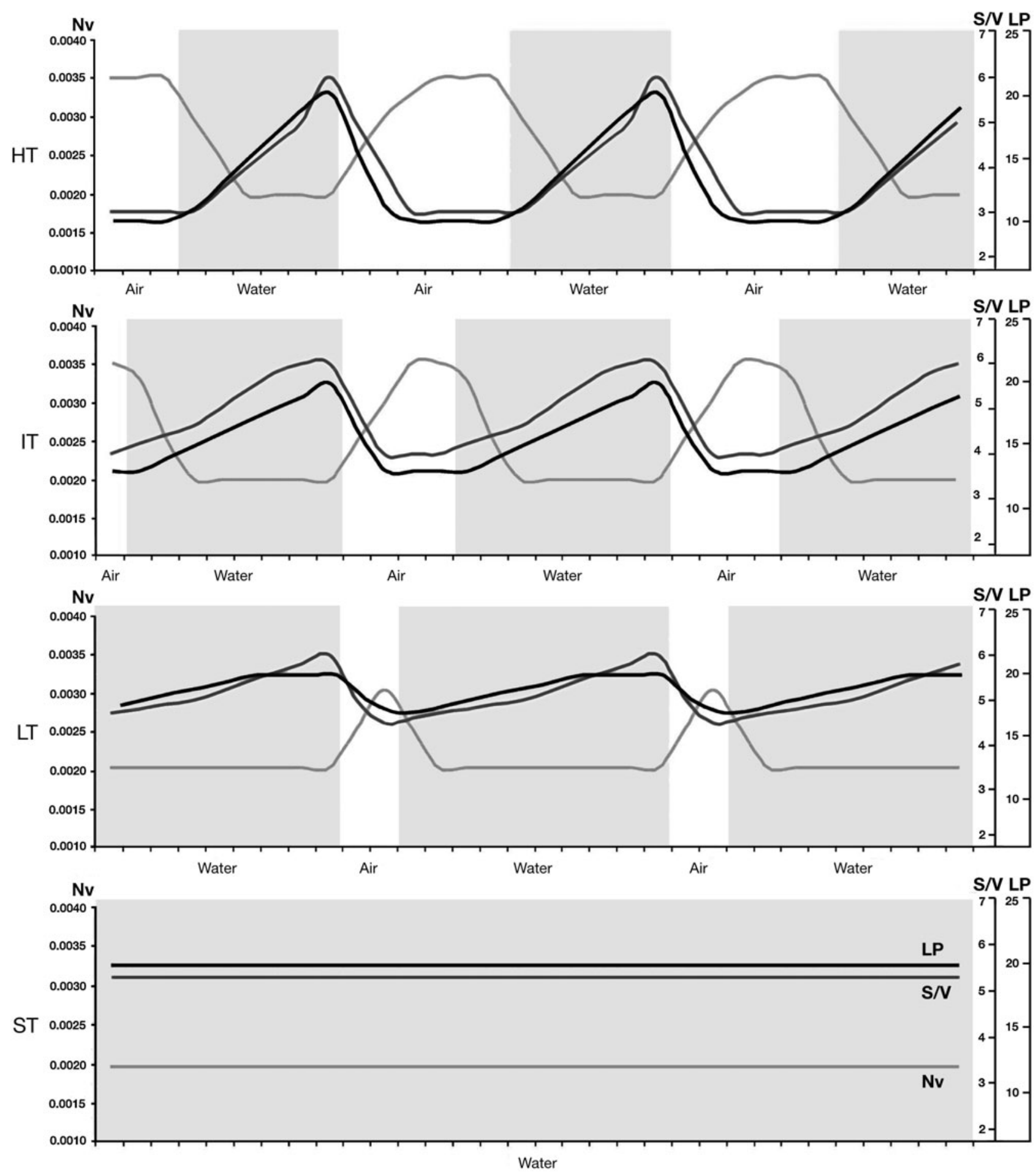

Fig. 7. Hypothetical model that would explain the present observations of changes in size (lysosomal surface to volume ratio, S/V) numbers (lysosomal numerical density, Nv) and membrane stability (labilisation period, LP) in digestive cell lysosomes with different intracellular digestion rhythms throughout the tidal cycle. Mytilus galloprovincialis mussels from high tidemark (HT): $>2.5 \mathrm{~m}$; intertidal (IT): 2.5 to $1.5 \mathrm{~m}$; low tidemark (LT): 1.5 to $0.5 \mathrm{~m}$; subtidal (ST): $<0.5 \mathrm{~m}$. The range of variation in lysosomal size, numbers and membrane stability would be higher in HT (cyclic intracellular digestion) than in ST mussels, (continuous intracellular digestion). Intertidal mussels would feed during immersion and intracellular digestion would progress during emersion (abundant and large lysosomes with destabilised membrane). Then, residual bodies would be excreted after the next emersion, as evidenced by reduced Nv and augmented LP values. As the time intervals for emersion and immersion change along the intertidal zone, the range of variation in lysosomal size, numbers and membrane stability would depend on the tidemark level where the mussels are located. Water: immersion period (grey); Air: emersion period 
On the other hand, lysosomal membrane is more destabilised in HT than in LT mussels both in summer and winter; however, the membrane is less destabilised in summer than in winter among HT mussels and vice versa for LT mussels. In addition, lysosomes of LT mussels are larger in summer than in winter and larger in general than those of HT mussel, especially in summer. The fact that seasonality is especially relevant in LT mussels may be related to seasonal variations in food availability, which is much higher in summer than in winter (Madariaga \& Orive 1989, Orive et al. 2004). Accordingly, it has been reported that in intertidal mussels, feeding activity is higher in summer than in winter (Wong \& Cheung 2003). Other stress sources, such as reproductive (Etxeberria et al. 1995) and thermal stress (Tremblay et al. 1998) cannot be fully discarded a priori, but it seems reasonable that they would affect mussels from all tidemark levels equally, at least in qualitative terms, which is not indicated by the results obtained in this study.

\section{Lysosomal biomarkers in environmental monitoring}

Apart from its contribution to the understanding of the lysosomal responses to external stimuli and of the form and function of the endo-lysosomal system of mussel digestive cells, the present investigation has relevant implications for the application of lysosomal biomarkers in marine ecosystem health monitoring.

It has been concluded that lysosomal parameters of mussel digestive cells change within $1 \mathrm{~h}$ after immersion or emersion throughout the tidal cycle (i.e. A mussels in Expt 2 and air-exposed HT mussels in Expt 3). Thus if, after collection in routine samplings of monitoring programmes, mussels are transported (in water or in air) to be processed in the laboratory, lysosomal $\mathrm{LP}, \mathrm{Vv}, \mathrm{Sv}, \mathrm{S} / \mathrm{V}$ and Nv may change as digestion progresses. Consequently, it is highly recommended that dissections be carried out in situ as soon as possible after sample collection.

Overall, it can be concluded that LT mussels are the most adequate sentinels for marine health monitoring programmes, as their digestive cell lysosomes undergo fewer changes in the course of the daily life cycle. Nevertheless, since digestive cell lysosomes in LT mussels exhibit a pattern of seasonal variation, the range of variation for each particular study area must be established in order to design a proper sampling strategy in monitoring programmes. Thus, whereas along the
Adriatic coast, lysosomal biomarkers do not show a strong dependence on season (Petrovic et al. 2004), along the Basque coast seasonality is crucial (Etxeberria et al. 1995) and winter samples appear to be meaningless as regards lysosomal biomarkers (Marigómez et al. 2006, Orbea et al. 2006). Particularly, in our study area, mussels collected around $1 \mathrm{~m}$ tidemark level are the best (or at least mussels below the 0.5 and above the $2 \mathrm{~m}$ tidemark levels should be discarded), since minor variability occurs between the 0.5 and $1.5 \mathrm{~m}$ tidemark levels in the studied lysosomal parameters and, in addition, seasonal variability is kept at a minimum in these mussels. Critical values of lysosomal biomarkers for these mussels to be used as sentinels in monitoring programmes are given in Table 1 .

Acknowledgements. Funded by pre-doctoral fellowships from the Basque Government to U. I., the research projects IMPRES (ETORTEK-Basque Government), PRESTEPSE (VEM200320082-C06-01, CICYT) and BEEP (EVK3-2000-00025, EC), and by a grant to Consolidated Research Groups (CBET Res Grp, UPV/EHU \& Basque Government).

\section{LITERATURE CITED}

Abele D, Burlando B, Viarengo A, Pörtner HO (1998) Exposure to elevated temperatures and hydrogen peroxide elicits oxidative stress and antioxidant response in the Antarctic intertidal limpet Nacella concinna. Comp Biochem Physiol 120B:425-435

Baumard P, Budzinski H, Garrigues P, Dizer H, Hansen PD (1999) Polycyclic aromatic hydrocarbons in recent sediments and mussels (Mytilus edulis) from Western Baltic Sea: occurrence, bioavailability and seasonal variations. Mar Environ Res 47:17-47

Cáceres-Martínez J, Figueras A (1998) Long-term survey on wild and cultured mussels (Mytilus galloprovincialis Lmk) reproductive cycles in the Ría de Vigo (NW Spain). Aquaculture 162:141-156

Cajaraville MP, Marigómez JA, Angulo E (1989) A stereological survey of lysosomal structure alterations in Littorina littorea exposed to 1-naphtol. Comp Biochem Physiol 93C: 231-237 
Cajaraville MP, Abascal I, Etxeberria M, Marigómez I (1995) Lysosomes as cellular markers of environmental pollution: time- and dose dependent responses of the digestive lysosomal system of mussels after petroleum hydrocarbon exposure. Environ Toxicol Water Qual 10: $1-8$

> Cajaraville MP, Garmendia L, Orbea A, Werding R and others (2006) Signs of recovery of mussels health two years after the Prestige oil spill. Mar Environ Res 62:S337-S341

Cancio I, Ibabe A, Cajaraville MP (1999) Seasonal variation of peroxisomal enzyme activities and peroxisomal structure in mussels Mytilus galloprovincialis and its relationship with the lipid content. Comp Biochem Physiol 123C: 135-144

> Charles F, Newell RIE (1997) Digestive physiology of the ribbed mussel Geukensia demissa (Dillwyn) held at different tidal heights. J Exp Mar Biol Ecol 209:201-213

de Madariaga I, Orive E (1989) Spatio-temporal variations of size-fractioned primary production in the Gernika estuary. J Exp Mar Biol Ecol 127:273-288

> Domouhtsidou GP, Dimitriadis VK (2000) Ultrastructural localization of heavy metals $(\mathrm{Hg}, \mathrm{Ag}, \mathrm{Pb}$, and $\mathrm{Cu})$ in gills and digestive gland of mussels, Mytilus galloprovincialis (L.). Arch Environ Contam Toxicol 38:472-478

Etxeberria M, Sastre I, Cajaraville MP, Marigómez I (1994) Digestive lysosome enlargement induced by experimental exposure to metals $(\mathrm{Cu}, \mathrm{Cd}$, and $\mathrm{Zn})$ in mussels collected from a zinc-polluted site. Arch Environ Contam Toxicol 27: 338-345

- Etxeberria M, Cajaraville MP, Marigómez I (1995) Changes in digestive cell lysosomal structure in mussels as biomarkers of environmental stress in the Urdaibai estuary (Biscay coast, Iberian Peninsula). Mar Pollut Bull 30:599-603

Harrison FL, Berger R (1982) Effects of copper on the latency of lysosomal hexosaminidase in the digestive cells Mytilus edulis. Mar Biol 68:109-116

> Helmuth BST, Hofmann GE (2001) Microhabitats, thermal heterogeneity, and patterns of physiological stress in the rocky intertidal zone. Biol Bull 201:374-384

Hole LM, Moore MN, Bellamy D (1995) Age-related cellular and physiological reactions to hypoxia and hyperthermia in marine mussels. Mar Ecol Prog Ser 122:173-178

> Huang SC, Newell RIE (2002) Seasonal variations in the rates of aquatic and aerial respiration and ammonium excretion of the ribbed mussel, Geukensia demissa (Dillwyn). J Exp Mar Biol Ecol 270:241-255

> Hunt HL, Scheibling RE (2001) Predicting wave dislodgement of mussels: variation in attachment strength with body size, habitat, and season. Mar Ecol Prog Ser 213: $157-164$

ICES (2005) Report of the Working Group on Biological Effects of Contaminants (WGBEC), 18-22 April 2005, Reykjavik, Iceland. ICES CM 2005/E:08

Ivankovic D, Pavicic J, Erk M, Filipovic-Marijic V, Raspor B (2005) Evaluation of the Mytilus galloprovincialis Lam. digestive gland metallothionein as a biomarker in a longterm field study: Seasonal and spatial variability. Mar Pollut Bull 50:1303-1313

Izagirre U (2007) Contribution to the interpretation of lysosomal biomarkers in marine organisms based on the mechanistic understanding of the lysosomal responses to pollutants. PhD Thesis, University of the Basque Country, Bilbao

Krishnakumar PK, Casillas E, Varanasi U (1994) Effect of environmental contaminants on the health of Mytilus edulis from Puget Sound, Washington, USA. I. Cytochemical measures of lysosomal responses in the digestive cells using automatic image analysis. Mar Ecol Prog Ser 106: 249-261

Labarta U, Fernández-Reiriz MJ, Babarro JMF (1997) Differences in physiological energetics between intertidal and raft cultivated mussels Mytilus galloprovincialis. Mar Ecol Prog Ser 152:167-173

Langton RW (1977) Digestive rhythms in the mussel Mytilus edulis. Mar Biol 41:53-58

Leiniö S, Lehtonen KK (2005) Seasonal variability in biomarkers in the bivalves Mytilus edulis and Macoma balthica from the Northern Baltic Sea. Comp Biochem Physiol 140C: 408-421

> López JL, Mosquera E, Fuentes J, Marina A, Vázquez J, Alvarez G (2001) Two-dimensional gel electrophoresis of Mytilus galloprovincialis: differences in protein expression between intertidal and cultured mussels. Mar Ecol Prog Ser 224:149-156

Lowe DM, Clarke KR (1989) Contaminant induced changes in the structure of the digestive epithelium of Mytilus edulis. Aquat Toxicol 15:345-358

Lowe DM, Moore MN, Clarke KR (1981) Effects of oil in the digestive cells in mussels: quantitative alterations in cellular and lysosomal structure. Aquat Toxicol 1:213-226

Manduzio H, Monsinjon T, Galap C, Leboulenger F, Rocher B (2004) Seasonal variations in antioxidant defences in blue mussels Mytilus edulis collected from a polluted area: Major contributions in gills of an inducible isoform of $\mathrm{Cu} / \mathrm{Zn}$-superoxide dismutase and of glutathione S-transferase. Aquat Toxicol 70:83-93

Marigómez I (2007) Cell and tissue biology of the mussel (Mytilus galloprovincialis) digestive gland: a novel view of its form and function. In: Jordaens K, Van Houtte N, Van Goethem J, Backeljau T (eds) Proc Wold Congr Malacol, Unitas Malacologica, Antwerp Belgium, p 139

Marigómez I, Baybay-Villacorta L (2003) Pollutant-specific and general lysosomal responses in digestive cells of mussels exposed to model organic chemicals. Aquat Toxicol 64: $235-257$

Marigómez I, Orbea A, Olabarrieta I, Etxeberria M, Cajaraville MP (1996) Structural changes in the digestive lysosomal system of sentinel mussels as biomarkers of enviromental stress in mussel-watch programes. Comp Biochem Physiol 113C:291-297

Marigómez I, Lekube X, Cajaraville MP, Domouhtsidou G, Dimitriadis V (2005) Comparison of cytochemical procedures to estimate lysosomal biomarkers in mussel digestive cells. Aquat Toxicol 75:86-95

> Marigómez I, Soto M, Cancio I, Orbea A, Garmendia L, Cajaraville MP (2006) Cell and tissue biomarkers in mussel, and histopathology in hake and anchovy from Bay of Biscay after the Prestige oil spill (Monitoring Campaign 2003). Mar Pollut Bull 53:287-304

> Marigómez JA, Vega MM, Cajaraville MP, Angulo E (1989) Quantitative responses of the digestive-lysosomal system of winkles exposed to sublethal concentrations of cadmium. Cell Mol Biol 35:555-562

> Marigómez JA, Soto M, Angulo E (1991) Responses of winkles digestive cells and their lysosomal system to enviromental salinity changes. Cell Mol Biol 37:29-39

Moore MN (1976) Cytochemical demostration of latency of lysosomal hydrolases in digestive cells of the common mussel, Mytilus edulis, and changes induced by thermal stress. Cell Tissue Res 175:279-287

> Moore MN (1988) Cytochemical responses of the lysosomal system and NADPH-ferrihemoprotein reductase in molluscan digestive cells to environmental and experimental exposure to xenobiotics. Mar Ecol Prog Ser 46:81-89 
Moore MN (2004) Diet restriction induced autophagy: a lysosomal protective system against oxidative- and pollutantstress and cell injury. Mar Environ Res 58:603-607

Moore MN, Clarke RK (1982) Use of microstereology and quantitative cytochermistry to determine the effects of crude oil-derived aromatic hydrocarbons on lysosomal structure and function in a marine bivalve mollusc, Mytilus edulis. Histochem J 14:713-718

Moore MN, Viarengo A (1987) Lysosomal membrane fragility and catabolism of cytosolic proteins: evidence for a direct relationship. Experientia 43:320-323

Moore MN, Lowe DM, Fieth PEM (1978) Lysosomal responses to experimentally injected anthracene in the digestive cells of Mytilus edulis. Mar Biol 48:297-302

Moore MN, Lowe DW, Moore SL (1979) Induction of lysosomal destabilisation in a marine bivalve mollusc exposed to air. Mar Biol Lett 1:47-57

Moore MN, Pipe RK, Farrar SV, Thompson S, Donkin P (1987) Lysosomal and microsomal responses to oil-derived hydrocarbons in Littorina littorea. In: Capuzzo JM, Kester DR (eds) Oceanic processes in marine pollution, Vol 1. Robert E. Krieger, Malobar, FL, p 89-96

Morton BS (1983) Feeding and digestion in bivalvia. In: Saleuddin ASM, Wilburg M (eds) The Mollusca, 5. Academic Press, New York, p 65-147

Nott JA, Moore MN (1987) Effects of polycyclic hydrocarbons on molluscan lysosomes and endoplastic reticulum. Histochem J 19:357-368

> Orbea A, Garmendia L, Marigómez I, Cajaraville MP (2006) Effects of the 'Prestige' oil spill on cellular biomarkers in intertidal mussels: results of the first year of studies. Mar Ecol Prog Ser 306:177-189

Orive E, Franco J, Madariaga I, Revilla M (2004) Bacteriplankton and phytoplankton communities. In: Borja A, Collins M (eds) Oceanography and marine environment of the Basque Country. Elsevier Oceanogr Ser 70, Elsevier BV, Amsterdam, p 367-394

Petrovic S, Semencic L, Ozretic B, Ozretic M (2004) Seasonal variations of physiological and cellular biomarkers and their use in the biomonitoring of North Adriatic coastal waters (Croatia). Mar Pollut Bull 49:713-720

Pipe RK, Moore MN (1985) Ultrastructural changes in the lysosomal-vacuolar system in digestive cells of Mytilus edulis as a response to increased salinity. Mar Biol 87: 157-163

Regoli F (1992) Lysosomal responses as a sensitive stress index in biomonitoring heavy metal pollution. Mar Ecol Prog Ser 84:63-69

Regoli F, Nigro M, Orlando E (1998) Lysosomal and antioxidant responses to metals in the Antartic scallop Adamussium colbecki. Aquat Toxicol 40:375-392

Ringwood AH, Hoguet J, Keppler CJ (2002) Seasonal variation in lysosomal destabilization in oysters, Crassostrea virginica. Mar Environ Res 54:793-797

Robinson WE, Langton RW (1980) Digestion in a subtidal population of Mercenaria mercenaria (Bivalvia). Mar Biol 58: 173-179

Robledo Y, Cajaraville MP (1996) Ultrastuctural and cytochemical study of the Golgi complex of molluscan (Mytilus

Editorial responsibility: Hans Heinrich Janssen, Oldendorf/Luhe, Germany galloprovincialis) digestive cells. Cell Tissue Res 284: 449-458

Sadok S, Uglow RF, Haswell SJ (1999) Some aspects of nitrogen metabolism in Mytilus edulis: effects of aerial exposure. Mar Biol 135:297-305

Saez V, Marigómez JA, Angulo E, Moya J (1990) Histomorphology and histochemistry of the digestive gland of Littorina littorea (L.) in relation to experimental tidal conditions, food availability, and digestion. Zool Jahrb. Abt Anatom Ontog Tiere 120:185-196

> Santarem MM, Robledo JAF, Figueras A (1994) Seasonal changes in hemocytes and serum defense factors in the blue mussel Mytilus galloprovincialis. Dis Aquat Org 18: $217-222$

Soto M, Kortabitarte M, Marigómez I (1995) Bioavailable heavy metals in estuarine waters as assessed by metal/shell-weight indices in sentinel mussels Mytilus galloprovincialis. Mar Ecol Prog Ser 125:127-136

Stickle WB, Moore MN, Bayne BL (1985) Effects of temperature, salinity and aerial exposure on predation and lysosomal stability of the dogwelk Thais (Nucella) lapillus (L.). J Exp Mar Biol Ecol 93:235-258

> Tremblay R, Pellerin-Massicotte J (1997) Effect of the tidal cycle on lysosomal membrane stability in the digestive gland of Mya arenaria and Mytilus edulis (L.). Comp Biochem Physiol 117:99-104

> Tremblay R, Myrand B, Guderley H (1998) Temporal variation of lysosomal capacities in relation to susceptibility of mussels, Mytilus edulis, to summer mortality. Mar Biol 132: 641-649

UNEP/RAMOGE (1999) Manual on the biomarkers recommended for the MED POL biomonitoring program. UNEP, Athens

Viarengo A, Moore MN, Pertica M, Mancinelli G, Accomando $\mathrm{R}$ (1992) A simple procedure for evaluating the protein degradation rate in mussel tissues and its application in a study of phenanthrene effects on protein catabolism. Comp Biochem Physiol 103B:27-32

- Wong WH, Cheung SG (2001) Feeding rhythms of the greenlipped mussel, Perna viridis (Linnaeus, 1758) (Bivalvia: Mytilidae) during spring and neap tidal cycles. J Exp Mar Biol Ecol 257:13-36

> Wong WH, Cheung SG (2003) Seasonal variation in the feeding physiology and scope for growth of green mussels, Perna viridis in estuarine Ma Wan, Hong Kong. J Mar Biol Assoc UK 83:543-552

Zaldibar B, Cancio I, Marigómez I (2004) Circatidal variation in epithelial cell proliferation in the mussel digestive gland and stomach. Cell Tissue Res 318:395-402

Zaldibar B, Cancio I, Marigómez I (2008) Epithelial cell renewal in the digestive gland and stomach of mussels: season, age and tidal regime related variations. Histol Histopathol 23:281-290

Zardi GI, Nicastro KR, Porri F, McQuaid CD (2006) Sand stress as non-determinant of habitat segregation in indigenous (Perna perna) and invasive (Mytilus galloprovincialis) mussels in South Africa. Mar Biol 148: 1031-1038

Submitted: February 25, 2008; Accepted: July 17, 2008 Proofs received from author(s): November 10, 2008 